\title{
The use of GIS INTEGRO in searching tasks for oil and gas deposits
}

\author{
E. N. Cheremisina, A. E. Senner ${ }^{a}$ \\ All-Russian Research Institute of geological, geophysical and geochemical systems, \\ Russia, 117105, Moscow, Varshavskoe Rd., 8 \\ E-mail: asenner_a_e@mail.ru
}

Received February 20, 2015

GIS INTEGRO is the geo-information software system forming the basis for the integrated interpretation of geophysical data in researching a deep structure of Earth. GIS INTEGRO combines a variety of computational and analytical applications for the solution of geological and geophysical problems. It includes various interfaces that allow you to change the form of representation of data (raster, vector, regular and irregular network of observations), the conversion unit of map projections, application blocks, including block integrated data analysis and decision prognostic and diagnostic tasks.

The methodological approach is based on integration and integrated analysis of geophysical data on regional profiles, geophysical potential fields and additional geological information on the study area. Analytical support includes packages transformations, filtering, statistical processing, calculation, finding of lineaments, solving direct and inverse tasks, integration of geographic information.

Technology and software and analytical support was tested in solving problems tectonic zoning in scale 1:200000, 1:1000000 in Yakutia, Kazakhstan, Rostov region, studying the deep structure of regional profiles 1:S, 1-SC, 2-SAT, 3-SAT and 2-DV, oil and gas forecast in the regions of Eastern Siberia, Brazil.

The article describes two possible approaches of parallel calculations for data processing $2 \mathrm{D}$ or $3 \mathrm{D}$ nets in the field of geophysical research. As an example presented realization in the environment of GRID of the application software ZondGeoStat (statistical sensing), which create 3D net model on the basis of data $2 \mathrm{~d}$ net. The experience has demonstrated the high efficiency of the use of environment of GRID during realization of calculations in field of geophysical researches.

Keywords: parallel calculations, GRID, geophysical research, data processing, 3D net model, GIS INTEGRO, ZondGeoStat

Citation: Computer Research and Modeling, 2015, vol. 7, no. 3, pp. 439-444. 


\section{Применение ГИС ИНТЕГРО в задачах поиска месторождений нефти и газа}

\section{Е. Н. Черемисина, А. Е. Сеннер}

Всероссийский научно-исследовательский институт геологических, геофизических и геохимических систем, Россия, 117105, г. Москва, Варшавское ш., д. 8

В основу системы интегрированной интерпретации геофизических данных при изучении глубинного строения Земли положена система ГИС ИНТЕГРО, являющаяся геоинформационной системой функционирования разнообразных вычислительных и аналитических приложений при решении различных геологических задач. ГИС ИНТЕГРО включает в себя многообразные интерфейсы, позволяющие изменять форму представления данных (растр, вектор, регулярная и нерегулярная сеть наблюдений), блок преобразования картографических проекций, а также прикладные блоки, включающие блок интегрированного анализа данных и решения прогнозно-диагностических задач.

Методический подход базируется на интеграции и комплексном анализе геофизических данных по региональным профилям, геофизических потенциальных полей и дополнительной геологической информации на изучаемую территорию.

Аналитическое обеспечение включает пакеты трансформаций, фильтрации, статистической обработки полей, расчета характеристик, выделения линеаментов, решения прямых и обратных задач, интегрирования геоинформации.

Технология и программно-аналитическое обеспечение апробировались при решении задач тектонического районирования в масштабах 1:200000, 1:1000000 в Якутии, Казахстане, Ростовской области, изучения глубинного строения по региональным профилям 1:ЕВ, 1-СБ, 2-СБ, 3-СБ и 2-ДВ, прогноза нефтегазоносности в районах Восточной Сибири, Бразилии.

Ключевые слова: параллельные вычисления, ГРИД, геофизические исследования, обработка данных, 3D сетевая модель, GIS INTEGRO, ZondGeoStat 
The building of the models of bowels of the earth is an actual problem, both with standpoint of the scientific studies, and with standpoint of practical activity mankind.

The scientific aspect of the decision this is attempts of understanding the processes of the formation and evolutions of our planet. Practical - in forecasting and searching of extractable natural resources for our vital activity. The rash technical progress during last two centuries has generated the huge amount absolutely new devices, technologies, materials. The amounts industrial production grows in groups of ten and a hundreds once. This has brought about need cutting the increase the mining as traditional resource (coal, oil, ore etc.) so and extractable natural resources practically not claimed earlier (the uranium, nickel, aluminum etc.). On expert estimations in surface layer of the earth (the depth not more 1 kilometer), available to mining useful resources by traditional technology, is extracted more than 70 percents useful extractable natural resources already.

Enumerated above and some other factors illustrate urgency of the building of the models of bedding of recourses for the reason forecasting, detailed elaboration and estimations of the volumes and extractable natural resources useful fossilized. GIS INTEGRO provides:

The building of the models is based on data processing the geophysical measurements, got by different methods of the geological exploring. Date in most cases present itself regular two-dimensional or three-dimensional network. A network node contains values of measured geophysical parameters (for instance, gravitation gradient, magnetic field value, etc.).

In our institute designed and developed software complex GIS INTEGRO, designed for processing of geophysical data. It is Russian innovation technology for solution of nature-use problems.

GIS INTEGRO provides:

Techniques and tools for integrated data analysis.

Regional forecast of oil and gas perspectives.

Environmental monitoring of oil-and- gas bearing regions.

Information and analytical support of nature-use management.

With standpoint of the processing for building of the models of earth bowels need mention the following typical features the data:

Large and very large volume. So, for instance, network of the size $100 \times 100 \times 20$ contains $2 \cdot 10^{5}$ nodes. Every node contains several values of the physical values. Image such small network contains the order of a million of values. In practice meets need of the processing the networks, containing too much values. The volume given herewith exceeds 2 Gbytes - greatly possible volume for keeping in operative memory the most wide-spread IBM PC computer architectures.

Possibility to ambiguous interpretation to observed anomaly. Revealed as a result of processing spottiness can be caused either as significant on its size anomaly, located from surface deeply, so and small anomaly, lying to surfaces close.

Enumerated above factors (either as variety of other) determine at building of the models of earth bowels use complex algorithms data processing, multipass processing the same material at variation of importance's parameter processing, use statistical and iterative methods of the processing. One pass calculation time maybe forms several hours, and in some case can reach the tens of hours.

The appearance of the environment GRID create the possibility of the considerable reduction execution time for some classes of geophysical tasks, were multisequencing of the process data processing possible.

This article discuss two the most perspective approaches of the multisequencing, not requiring significant modification existing software and giving significant advantage on time performing the calculation.

\section{The first approach}

The typical particularity of the three-dimensional nets in the field of geophysics is vastly greater amount of the nodes on axes $\boldsymbol{X}$ and $\boldsymbol{Y}$ (the plane $\boldsymbol{X O Y}$ is parallel earth surface) in contrast with amount of the nodes on $\boldsymbol{Z}$ axis ( $\boldsymbol{Z}$ is directed vertically downwards) (Fig. 1.). The reason - is quick growth of relative error of the measurements with depth and brings about small validity of the deep measurements. 


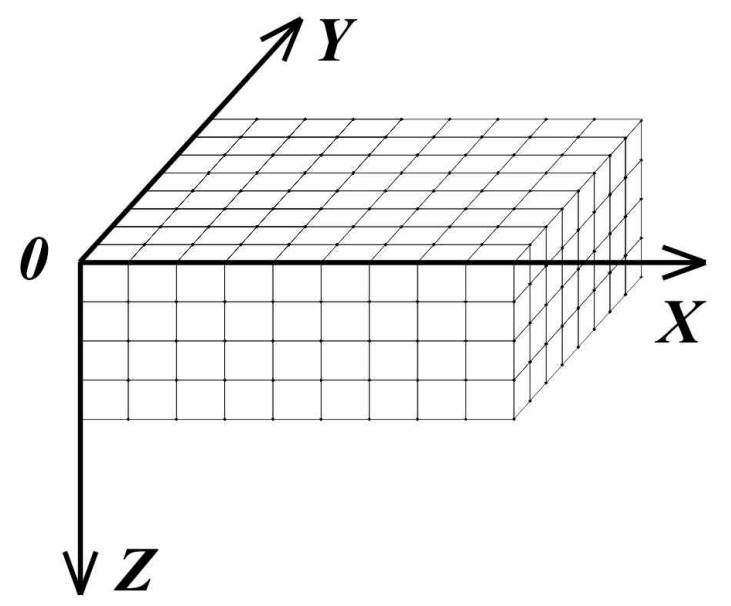

Fig. 1. Typical geophysics data network

Exists the extensive class of the tasks, which algorithms are based on calculation in each network node of the certain values as a surrounded nodes function, removed from base node not far then any value $R$. In this case possible following scheme of the multisequencing.

The source net divides on separate fragments by vertical planes paralleled $\boldsymbol{Z O X}$ or $\boldsymbol{Z O Y}$. The processing algorithm placed in nodes GRID parametric tunes in on processing single specified fragment. Processing of each fragment is produced by separate node GRID, which is sent whole net. After termination of the processing all fragment in nodes GRID got results are integrated in resulting net and are delivered researcher (Fig. 2).

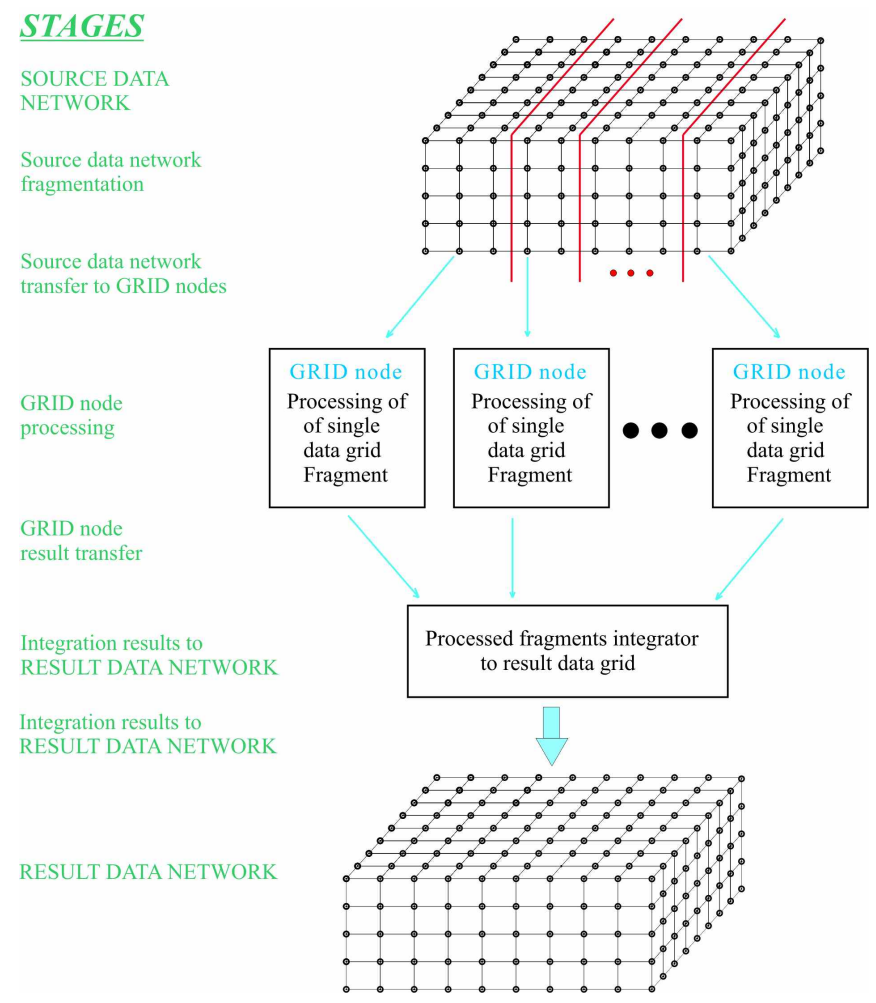

Fig. 2. Scheme of processing using GRID

The algorithms of integrations result usually it is enough simple and require not big running time. Therefore it possible considers that reduction of calculation time proportional to account of the amount fragment partition. 
If source network great, that possible optimization of volume transferring data. To GRID node transfer only extended fragment, consisting directly of fragment plus nodes removed no more than on $\boldsymbol{R}$ from border nodes of the fragment of the net (Fig. 3). The amount real transferred data decrease in this case proportional to amount of source net fragments.

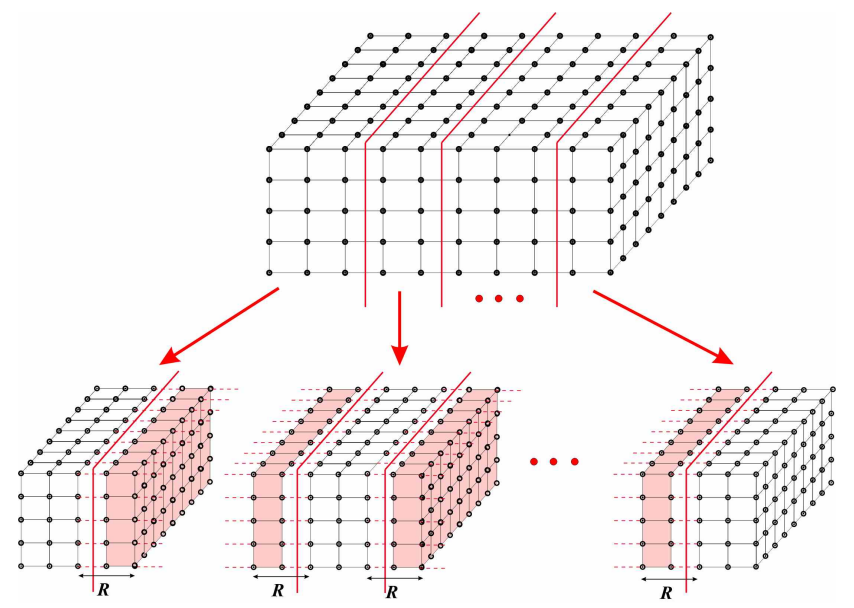

Fig. 3. Transfer optimization

The volume of the issues possible to optimize, sending to GRID node only extended fragment, consisting directly of fragment plus nodes removed no more than on $\boldsymbol{R}$ from border nodes of the fragment of the net.

\section{The second approach}

Realization of software package ZondGeoStat (statistical sounding) for finding linear anomaly by vector flap in 2D task of the geophysical studies demonstrates second approach of the possibility of the use the multisequencing. Statistical sounding allows provide tracing the statistical parameters in the moving changing size window. It allows to go to $\mathbf{3 D}$ object, carrying information on deep construction of the earth of the under investigation territory.

The algorithm of package is based on calculation of the necessary features inwardly certain square area of the fixed size, named by window. The centre of window complies with one of the nodes of the net. The results of the calculation single window fit are situated in central node window. The single pass of the calculation consists in processing all possible fixed size windows (Fig. 4), where $\boldsymbol{N} \boldsymbol{x}$, $\boldsymbol{N} \boldsymbol{y}$ - are number of nodes $\boldsymbol{X}$ and $\boldsymbol{Y}$ axis, $\boldsymbol{R}$ - size of current window:

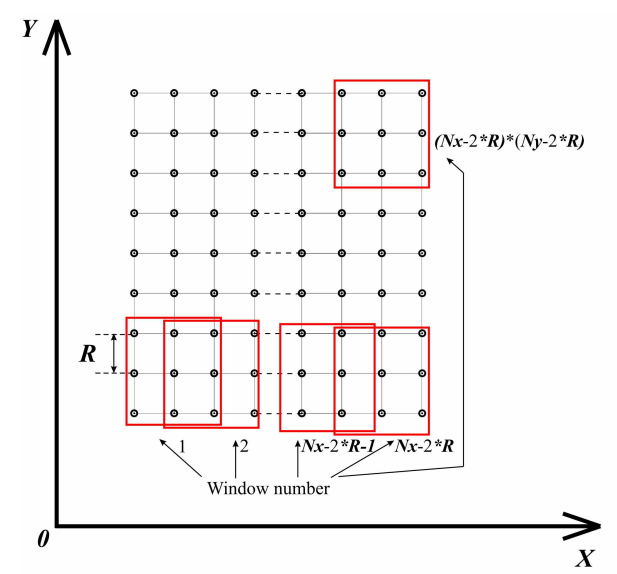

Fig. 4. Single pass. $\mathrm{R}=1$ 
The Following single pass differs the size used window (Fig. 5).

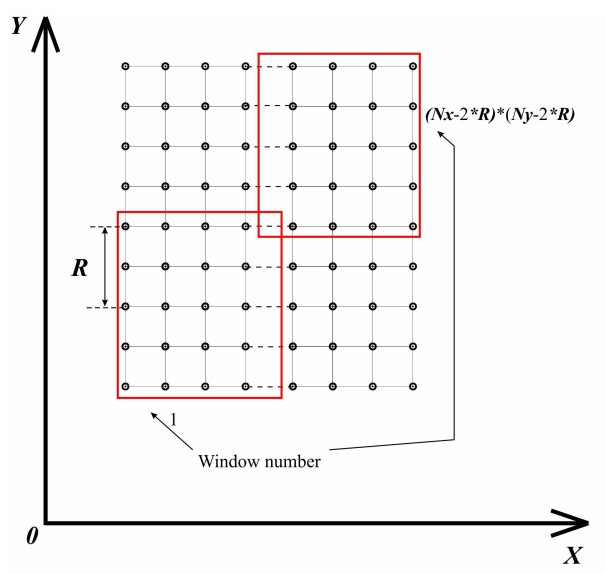

Fig. 5. Single pass. $\mathrm{R}=2$

Accordingly on following stage of the calculation changes the size a window and procedure of the calculation is repeated.

The finally calculation is collection of the calculation of the set of the different size windows. The typical amount of the different sizes window under given study forms from 10 up 30 .

Created in GRID environment realization of ZondGeoStat use individual GRID node for calculating of single pass, in other words for processing all source data grid by fixed size window. So logical scheme of using GRID environment in this case very similar to scheme of Figure 1.

\section{Conclusion}

The derived experience has demonstrated high efficiency of the of use GRID environment in the field of geophysical and geological investigations.

It seems perspective further adaptation other software package data processing in GRID environment.

\section{References}

Демичев А. П., Ильин В. А., Крюков А. П. Введение в ГРИД-технологии // Препринт НИИЯФ МГУ. — 2007. — 11/832. - M., 2007. URL: http://egee.pnpi.nw.ru/doc/pp-832.pdf.

Черемисина Е. Н., Никитин А. А. Геоинформационные системы и технологии. - М.: ВНИИгеосистем, 2011. 